\title{
A Combination of Derepression of the lac Operator-Repressor System with Positive Induction by Glucocorticoid and Metal Ions Provides a High-Level-Inducible Gene Expression System Based on the Human Metallothionein- $\mathrm{II}_{\mathrm{A}}$ Promoter
}

\author{
MICKEY C.-T. HU ${ }^{*}$ AND NORMAN DAVIDSON \\ Division of Biology, California Institute of Technology, Pasadena, California 91125
}

Received 11 June 1990/Accepted 24 September 1990

\begin{abstract}
We and others have introduced the use of the lac operator-repressor system as a method for providing inducible gene expression for gene transfer experiments in animal cells (M. C.-T. Hu, and N. Davidson, Cell 48:555-566, 1987; J. Figge, C. Wright, C. J. Collins, T. M. Roberts, and D. M. Livingston, Cell 52:713-722, 1988). To improve the dynamic range of such an inducible system, we have investigated the effects of combining the relief by isopropyl- $\beta$-D-thiogalactoside (IPTG) of negative control by the lac system with positive induction by the natural inducers glucocorticoids and cadmium ion for a system based on the human metallothionein-II gene promoter. We used the chloramphenicol acetyltransferase gene as a reporter gene and inserted a lacO sequence into the promoter between the GC box and metal-responsive element 1 , between metal-responsive element 1 and the TATA box, or between the TATA box and the transcription start site. Surprisingly, all of these insertions had a significant inhibitory effect on promoter activity even in the absence of repressor. However, with these lac $O$-containing constructs, the levels of gene expression after induction by glucocorticoid, $\mathrm{Cd}^{2+}$, or both were considerably reduced in cells engineered to express the lac repressor. Derepression by IPTG, coupled with induction by both dexamethasone and $\mathrm{Cd}^{2+}$ ion, then provided a high level of induced expression, i.e., by a factor of approximately 100 over the basal level of expression. However, inserting the lac $O$ sequence well upstream just before the glucocorticoid-responsive element had much smaller effects on expression levels in both repressor-negative and repressor-positive cells. This study describes a new, high-levelinducible promoter system for gene transfer experiments. The observed effects are discussed in terms of current models of the mechanisms by which transcription factors control gene expression.
\end{abstract}

Inducible promoter systems are very useful for controlling the levels of gene expression of transfected genes for basic studies of the cell biological effects of a given gene product and, in some cases, for practical genetic engineering applications. We and others have previously described the use, in mammalian cells, of the lac operator-repressor system for this purpose $(6,9,11,15,16,25)$. It was shown that insertion of the lac operator (lacO) into an otherwise constitutive eucaryotic promoter provided lacI-dependent expression when the genes were transfected into eucaryotic cells. Furthermore, treatment of the $\mathrm{lacI}^{+}$cells with isopropyl- $\beta$ D-thiogalactoside (IPTG) resulted in significant derepression. Thus, the lac operator-repressor system was shown to be potentially useful for the design of inducible gene expression systems for transfected genes. This system may be particularly attractive for use with eucaryotic cells and organisms because the inducer, IPTG, does not occur in tissue culture media or in body fluids.

However, the levels of induction by IPTG observed by us for a chimeric Moloney sarcoma virus simian virus 40 (SV40) enhancer-promoter combination were at best 10:1 to $20: 1$ (15). The study presented here describes an effort to achieve higher levels of inducibility in combination with a high level of gene expression in the induced state. We reasoned that if

\footnotetext{
* Corresponding author.

† Department of Pathology, Stanford University School of Medicine, Stanford, CA 94305-5427.
}

one could insert the $\mathrm{lac} O$ sequence into an inducible eucaryotic promoter in such a way that the positive induction by the cognate inducer and the relief by IPTG of repression by the lac repressor were independent events, the overall induction ratio should be multiplicative.

We chose the promoter of the human metallothionein $\mathrm{II}_{\mathrm{A}}$ $\left(\mathrm{hMT}-\mathrm{II}_{\mathrm{A}}\right.$ ) gene. This gene is actively expressed in most cell types, and its transcription is regulated in response to a variety of environmental stimuli, including heavy-metal ions, steroid and polypeptide hormones, growth factors, cytokines, and phorbol ester tumor promoters $(12,18,20$, $21)$. These effects are mediated by specific regulatory proteins that interact with distinct cis-acting elements in the $5^{\prime}$-flanking region of the gene $(1,21,23,24)$. In addition to containing one glucocorticoid-responsive element (GRE) and four metal ion responsive elements (MREs), the 5'flanking region contains four elements known to be involved in controlling the basal level of expression: a TATA box, a GC box, and two basal-level enhancer elements (BLEs) (18). In the induced state, this promoter can provide levels of expression higher than those from, for example, a dexamethasone-induced mouse mammary tumor virus promoter (17).

In this study, we used a 30-nucleotide synthetic, fully symmetric lac $O$ operator segment that has been shown to bind repressor more strongly than does the native lac $O$ sequence (34) used in our earlier studies (15). We had observed previously that the wild-type lac repressor expressed in animal cells was distributed in a 9:1 ratio between cytoplasm and nucleus (15). To increase the concentration of 
repressor in the nucleus, we have recently designed a modified protein with the minimal SV40 T-antigen karyophilic sequence fused to the carboxy terminus of the lac repressor; we have observed that this modified repressor binds correctly to the lac $O$ sequence and is localized entirely in the nucleus (M. C.-T. Hu and N. Davidson, Gene, in press). We carried out the study described here in separate cell lines expressing either the wild-type or the modified repressor.

We found that a significant level of control of gene expression could be achieved by lac repressor binding to an inserted lacO segment and by derepression by IPTG. The negative effects of lac repressor binding on chloramphenicol acetyltransferase (CAT) expression were found to depend on the position of the lac $O$ insert relative to the sites of binding of some of the endogenous positive regulatory proteins. The implications of these results with respect to the mechanisms by which transcription factors regulate gene expression are discussed.

\section{MATERIALS AND METHODS}

Site-directed mutagenesis of the hMT-II promoter. A $-2865^{\prime}$ deletion mutant of the hMT-II promoter (21) linked to the herpes simplex virus $t k$ gene was kindly provided by Michael Karin (University of California, San Diego). This plasmid containing the $\mathrm{hMT}-\mathrm{II}_{\mathrm{A}}$ promoter was cleaved by restriction endonuclease $N c o I$, and the ends of this $N c o$ I site were repaired with Escherichia coli DNA polymerase I large fragment (Klenow) in the presence of four deoxynucleotide triphosphates. The promoter DNA fragment was excised by restriction endonuclease HindIII, gel isolated, and subcloned into the HindIII and HincII sites of the vector M13mp19 (40) to give $h M T-I_{A} / M 13 m p 19$. The synthetic oligonucleotide 5'-CGCCTCGGCATGCAAGGGGCT-3' (21mer) was used as a mutagenic primer to introduce three nucleotide mutations at a region between the GRE and BLE2 of the hMT-II promoter (Fig. 1A). The 5'-phosphorylated mutagenic primer and an M13-specific primer, 5'-AT GCCCCCTGCCTATTTCGG-3' (corresponding to nucleotides 2054 to 2073 of M13mp19), were simultaneously annealed to a single-stranded DNA template of $\mathrm{hMT}^{-\mathrm{II}_{\mathrm{A}} /}$ M13mp19, extended with Klenow enzyme, and ligated essentially as described previously (41). Following transformation into bacterial strain MC1061.2, the mutant clones were screened by dot blot analysis, using the ${ }^{32} \mathrm{P}$-labeled mutagenic primer as a probe. Double-stranded (replicativeform) DNA of the mutant clones was isolated and purified from plaque-purified phages, and the newly engineered $S p h I$ site was confirmed by restriction endonuclease digestion. In addition, the mutated nucleotides within the hMT- $\mathrm{II}_{\mathrm{A}}$ promoter were confirmed by dideoxy-chain termination sequencing (2) of the phage-derived, single-stranded DNA. In the same manner, the oligonucleotide 5'-ACGAGTGCGC ATGCCCCGCC-3' (20-mer) was used as a mutagenic primer to mutate three nucleotides at a region between the GC box and MRE1 (Fig. 1A). Thus, a unique $S p h I$ site was created in this region. Similarly, the oligonucleotide 5'-GAGTGCAG TACTGCAAGCAGTGTTTATAGCTCGAGAGAGCCGG-3' was used as a mutagenic primer to introduce simultaneously two nucleotide mutations at a region between MRE1 and the TATA box and three nucleotide mutations between the TATA box and the transcription start site (Fig. 1A). In this mutant clone, a unique $X$ hol site was generated between MRE1 and the TATA box, and a unique $S c a$ I site was generated between the TATA box and the transcription start site. Subsequently, all of the mutant $\mathrm{hMT}-\mathrm{II}_{\mathrm{A}}$ promoters were excised from the mutant M13 clones by digestion with restriction endonucleases HindIII and BamHI. These 370-bp HindIII-BamHI fragments were gel isolated and subcloned into the pUC ${ }^{\mathrm{PL}} \mathrm{CAT}$ vector (4), which does not contain a eucaryotic promoter for CAT gene expression in eucaryotic cells. This vector was digested with restriction endonucleases HindIII and BglII. The 4.4-kb HindIII-BglII fragment was isolated and ligated with the several 370-bp HindIII-BamHI promoter fragments with T4 DNA ligase. The vector also carried an SV40 small intron and a poly(A) addition signal for the expression of CAT protein in mammalian cells. Thus, the resulting vectors all contain an $\mathrm{hMT}-\mathrm{II}_{\mathrm{A}}$ promoter with point mutations to create unique restriction sites in an otherwise conventional CAT gene reporter construct.

Construction of the hMTCAT expression vectors containing lacO sequence inserts. The oligonucleotide $5^{\prime}$-TGTGGAATT GTGAGCGCTCACAATTCCACA-3' (30-mer), containing a symmetric lac $\mathrm{O}$ sequence (34), was self-annealed to form a blunt-ended double-stranded DNA segment. The latter was inserted by blunt-end ligation into each of the unique restric-

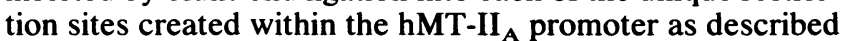
above, using standard methods and where necessary filling in restriction sites by repair with T4 DNA polymerase in the presence of nucleotides.

We also prepared several hMT-II promoter elements containing the 30 -nucleotide lac $O$ sequence flanked by what we hoped were innocuous spacer sequences of moderate length. This was accomplished by inserting the lac $O$ sequence into the BamHI site of pBR322, excising a 420-bp DNA fragment containing the lac $O$ sequence at its center by digestion with $E c o R V$, and adding a synthetic SphI linker. Thus, the resulting DNA fragment contained the 30-bp lacO sequence at the center with two flanking 190-bp DNA segments as spacers, one on each side. This segment was inserted at the unique $S p h I$ site at the -55 position of the mutant hMT-II A promoter or at the similar site at -226 .

Cell culture and DNA transfections. The cell lines used were Rat XC (American Type Culture Collection; ATCC CCL 165) and two derivatives, XC35-5 and XC36-2, prepared by us (Hu and Davidson, in press). XC35-5 cells had been stably transfected with DNA expressing the wild-type lacI gene. These cells expressed $2.2 \times 10^{5}$ functional molecules per cell, of which $2 \times 10^{4}$ were localized in the cell nucleus. XC36- 2 cells had been transfected with a similar construction expressing a modified lac repressor with the SV40 T-antigen nuclear localization signal (NLS) fused to its carboxy terminus. These cells expressed $5 \times 10^{3}$ functional repressors, all of which were localized in the cell nucleus. Cells were grown in plastic plates (Falcon) in Dulbecco modified Eagle medium (DME; GIBCO) supplemented with $10 \%$ fetal calf serum (FCS; GIBCO), penicillin $(100 \mathrm{U} / \mathrm{ml})$, and streptomycin $(100 \mu \mathrm{g} / \mathrm{ml})$. The antibiotic G418 (GIBCO) was added to the medium at a final concentration of $\mathbf{4 0 0}$ $\mu \mathrm{g} / \mathrm{ml}$ as needed. Cells were cultivated at $37^{\circ} \mathrm{C}$ in a humidified atmosphere containing $5 \% \mathrm{CO}_{2}$. For induction experiments, IPTG (Bethesda Research Laboratories) was prepared as a $1 \mathrm{M}$ stock solution in sterile distilled $\mathrm{H}_{2} \mathrm{O}$; dexamethasone (DEX; Sigma Chemical Co.) and $\mathrm{CdCl}_{2}$ (Sigma) were prepared as 1 and $5 \mathrm{mM}$ stock solutions, respectively, in phosphate-buffered saline $(140 \mathrm{mM} \mathrm{NaCl}, 10$ $\mathrm{mM}$ sodium phosphate, $\mathrm{pH}$ 7.4). For transient transfection, cells were plated on the day before transfection at a density of ca. $10^{6}$ cells per 60 -mm-diameter plastic plate (Falcon). DEAE-dextran transfections $(26,38)$ were performed by 
A

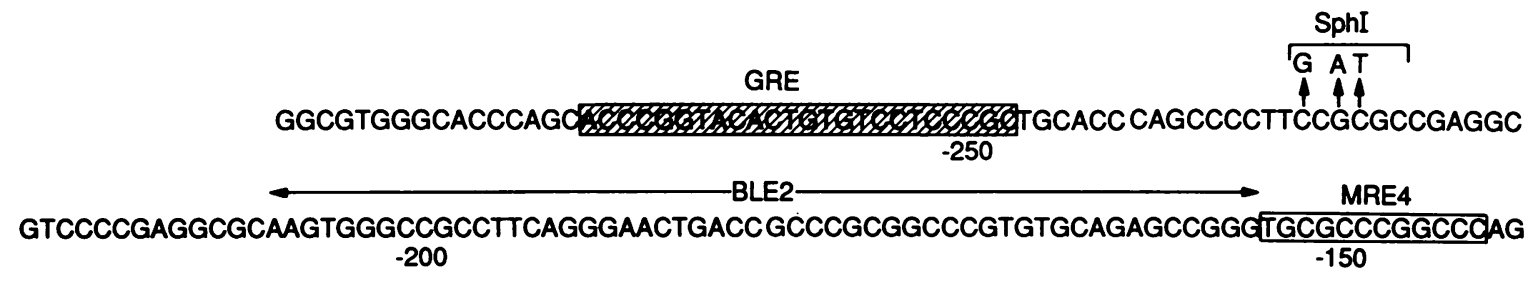

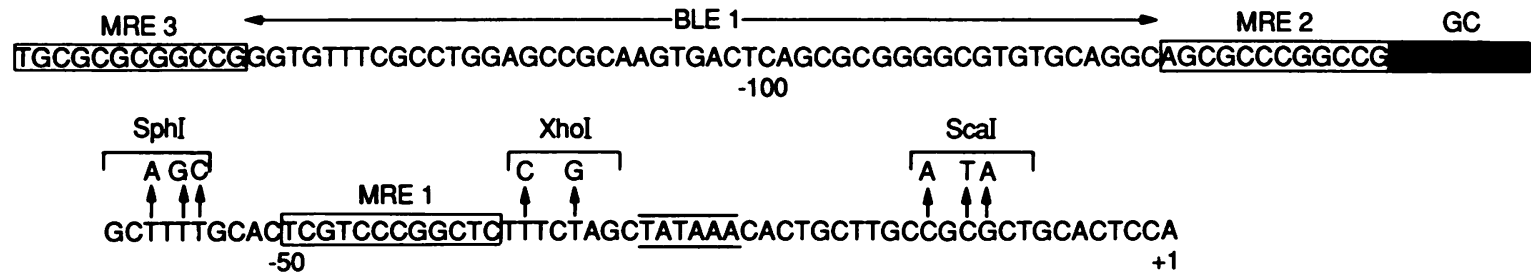

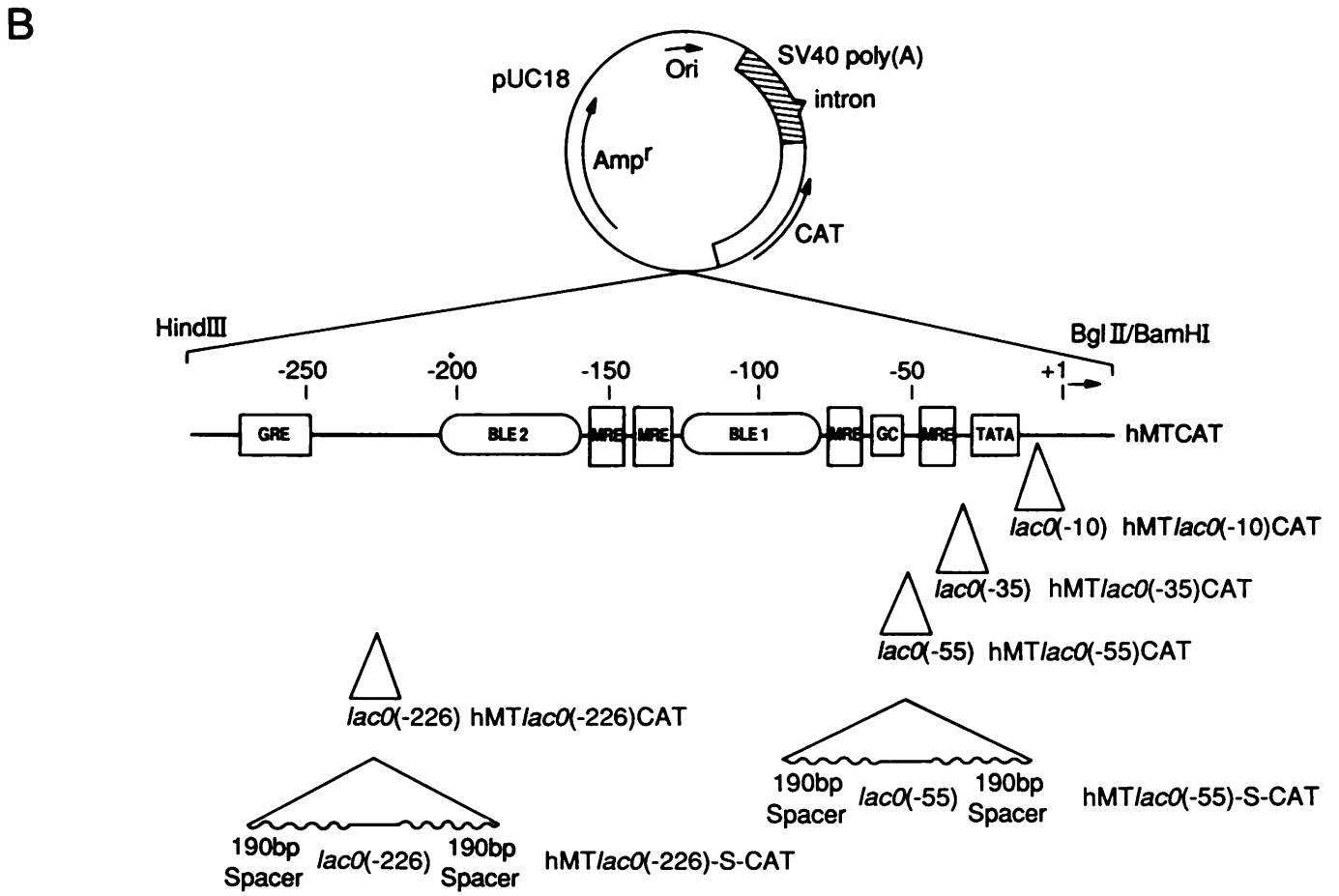

FIG. 1. Structures of chimeric hMT-II $\mathrm{A}_{\mathrm{A}}$ promoters carrying the lacO sequence. (A) Sequence of the hMT-II $\mathrm{A}_{\mathrm{A}}$ promoter region from position +1 (the major start site of transcription) to position -286 as described by Karin et al. (19). Upstream and proximal promoter elements, including the GRE, the MREs, the GC box, the BLEs, and a TATA box, are indicated. The mutated nucleotides are shown above the wild-type nucleotides $(\uparrow)$, and the resulting new restriction endonuclease sites are designated. (B) Schematic representation of the various hMTlacO-CAT constructs. The organization of the hMT- $\mathrm{II}_{\mathrm{A}}$ promoter (23) is shown below the diagram of the plasmid vector pUCCAT (4), which contains CAT-coding sequences, the SV40 small-t intron, and early poly(A) addition signal. The coding region of the CAT gene was linked to the various chimeric hMT-II promoters. Positions of the lacO insertion are indicated $\triangle$, and the position numbers are in parentheses. $\sim$, Spacer DNA segment (190 bp) flanking the lac $O$ sequence.

washing the cells twice with $5 \mathrm{ml}$ of DME without serum and then adding DEAE-dextran $(500 \mu \mathrm{g} / \mathrm{ml}$; molecular weight, 500,000 ; Pharmacia) in $2 \mathrm{ml}$ of DME with the appropriate DNA (at $2 \mu \mathrm{g} / \mathrm{ml})$ in the presence of chloroquine $(2 \mu \mathrm{g} / \mathrm{ml})$. After $4 \mathrm{~h}$ of incubation at $37^{\circ} \mathrm{C}$, the cells were shocked with dimethyl sulfoxide in buffer containing $137 \mathrm{mM} \mathrm{NaCl}, 5 \mathrm{mM}$
$\mathrm{KCl}, 0.7 \mathrm{mM} \mathrm{Na} \mathrm{HPO}_{4}, 6 \mathrm{mM}$ dextrose, and $21 \mathrm{mM} \mathrm{N}-2-$ hydroxyethylpiperazine- $N^{\prime}$-2-ethanesulfonic acid (HEPES) (pH 7.1) for 2 min at room temperature as described previously (26). After removal of the shock buffer, the cells were washed once with $2 \mathrm{ml}$ of phosphate-buffered saline and then incubated in $5 \mathrm{ml}$ of DME containing $10 \% \mathrm{FCS}$ in a $5 \% \mathrm{CO}_{2}$ 
$37^{\circ} \mathrm{C}$ incubator. After $12 \mathrm{~h}$ of incubation, the media were replaced with fresh media with or without inducers, and cells were incubated for $48 \mathrm{~h}$ before harvesting. For induction experiments, cells were given fresh media containing $20 \mathrm{mM}$ IPTG, $1 \mu \mathrm{M} \mathrm{DEX}$, and $5 \mu \mathrm{M} \mathrm{CdCl}_{2}$, alone and in combination. Each plasmid preparation used for transfection was purified through $\mathrm{CsCl}$-ethidium bromide equilibrium gradients. After transfection, the CAT extractions and assays were performed as described below. For stable transfection, XC36-2 cells (expressing the mutant lac repressor) were plated on the day before transfection at a density of ca. $2 \times$ $10^{6}$ cells per $100-\mathrm{mm}$-diameter dish. Plasmid DNA was introduced into these cells by the lipofection technique as described previously (10). Specifically, $100 \mu \mathrm{l}$ of DNA solution (10 mM Tris hydrochloride, $\mathrm{pH} 8.0$ ) containing 10 $\mu \mathrm{g}$ of either the hMTCAT or hMTlacO $(-55)$ CAT construct and $0.1 \mu \mathrm{g}$ of pY3 (3), which contains the hygromycin B (hmB) phosphotransferase gene, was mixed gently with 100 $\mu l$ of the Lipofectin reagent (Bethesda Research Laboratories), which contains the cationic lipid $N$-[1-(2,3-dioleylosy) propyl]-N,N,N-trimethylammonium chloride and dioleoyl phosphatidylethanolamine, in a polystyrene tube. Cells were washed twice with $10 \mathrm{ml}$ of DME without serum and incubated in $5 \mathrm{ml}$ of DME without serum. Then Lipofectin reagent-DNA complex was added dropwise to the cells with gentle swirling. After $20 \mathrm{~h}$ of incubation in a $5 \% \mathrm{CO}_{2} 37^{\circ} \mathrm{C}$ incubator, $5 \mathrm{ml}$ of DME containing $20 \%$ FCS was added and the cells were incubated for $48 \mathrm{~h}$ in the same incubator. Three days after transfection, the media were replaced with fresh DME containing $10 \%$ FCS, G418 $(200 \mu \mathrm{g} / \mathrm{ml})$, and hmB $(400 \mu \mathrm{g} / \mathrm{ml})$. Four individual G-418- and hmB-resistant colonies were trypsinized in cloning cylinders and transferred to plastic microtiter wells. The remaining G418- and hmBresistant colonies (ca. 80 to 100) were trypsinized, pooled, and transferred to plastic microtiter wells. Single and pooled clonal lines were expanded and maintained in DME supplemented with $10 \%$ FCS, G418 $(200 \mu \mathrm{g} / \mathrm{ml})$, and hmB (200 $\mu \mathrm{g} / \mathrm{ml})$. For induction experiments, cells were plated on the day before induction at a density of $10^{6}$ cells per $60-\mathrm{mm}$ diameter plastic plate. The media were replaced with fresh media containing $20 \mathrm{mM}$ IPTG, $1 \mu \mathrm{M}$ DEX, and/or $5 \mu \mathrm{M}$ $\mathrm{CdCl}_{2}$ as needed, and cells were incubated for $48 \mathrm{~h}$ before harvesting.

CAT assays. CAT assays were performed as described previously (14), with some modifications. After removal of the media from 60-mm-diameter plates, the cells were washed twice with $5 \mathrm{ml}$ of phosphate-buffered saline at room temperature. The cells were lysed directly on plates with 0.5 $\mathrm{ml}$ of CAT lysis buffer (0.25 M Tris hydrochloride [pH 7.8], $0.5 \%$ Nonidet P-40) for $5 \mathrm{~min}$ on ice. The solubilized and insoluble cellular materials were removed with a cell scraper and pipetted into a $1.5-\mathrm{ml}$ microcentrifuge tube. These samples were frozen in an ethanol-dry ice bath immediately for $5 \mathrm{~min}$ and thawed in a $37^{\circ} \mathrm{C}$ water bath for $5 \mathrm{~min}$. Presumably, this freeze-thaw step can prevent protein aggregation which may interfere with the enzymatic assay. Soluble extracts were prepared by centrifugation in a microcentrifuge at $4^{\circ} \mathrm{C}$ for $10 \mathrm{~min}$ to pellet the insoluble material. The protein content of each extract was determined by the method of Bradford (5), using a standard curve prepared with bovine immunoglobulin $G$ (Bio-Rad). Aliquots of extracts containing equal amounts of protein, either $100 \mu \mathrm{g}$ for transient expressions or $\mathbf{4 0 0} \mu \mathrm{g}$ for stable expressions, were brought to a final volume of $100 \mu$ l by addition of $0.25 \mathrm{M}$ Tris hydrochloride (pH 7.8) prior to assay. Extracts were incubated with $\left[{ }^{14} \mathrm{C}\right]$ chloramphenicol $(50 \mathrm{mCi} / \mathrm{mmol}$; Amersham) and acetyl coenzyme A (Sigma) for $2 \mathrm{~h}$ at $37^{\circ} \mathrm{C}$. Following thin-layer chromatography, CAT activity was quantitated by slicing the thin-layer chromatography plates and determining the radioactivity (counts per minute) contained in the spots corresponding to the acetylated $\left[{ }^{14} \mathrm{C}\right]$ chloramphenicol and $\left[{ }^{14} \mathrm{C}\right]$ chloramphenicol by liquid scintillation counting. The values of specific CAT enzyme activities, expressed as picomoles of $\left[{ }^{14} \mathrm{C}\right]$ chloramphenicol converted per milligram of protein per hour, are averages of four independent experiments from transient expression except for pUCCAT (two independent experiments) and of two independent experiments from stable expression.

Analysis of integrated CAT-containing plasmid DNA. Nuclear DNA was prepared as described elsewhere ( $\mathrm{Hu}$ and Davidson, in press) and subjected to Southern blot analysis after digestion with the restriction endonucleases BamHI and HindIII, followed by blotting with the labeled $2.1-\mathrm{kb}$ BamHI-HindIII DNA probe containing the entire CATcoding sequence as gel isolated from hMTCAT.

Deposition of plasmids. Plasmid constructs hMTCAT, hMTlac $O(-10)$ CAT, hMTlac $O(-35)$ CAT, hMTlacO(-55) CAT, hMTlacO(-226)CAT, hMTlacO(-55)-S-CAT, and hMTlacO(-226)-S-CAT described herein will be deposited with the American Type Culture Collection, Rockville, Md.

\section{RESULTS}

Description of chimeric hMT-II promoters carrying the lacO sequence. As described in Materials and Methods, the human $\mathrm{hMT}-\mathrm{II}_{\mathrm{A}}$ promoter was mutated to permit convenient insertion of a 30 -bp symmetric lac $O$ sequence between the TATA box and the transcription start point [hMTlacO $(-10)$ CAT], between the TATA box and MRE 1 [hMTlac $O(-35)$ CAT], between MRE 1 and the GC box [hMTlac $O(-55)$ CAT], and further upstream between BLE2 and the GRE [hMTlacO $(-226) \mathrm{CAT}]$. The sequence of the promoter and the positions of the several inserts are shown in Fig. 1.

In addition, a lac $O$ insert spaced on each side by $190 \mathrm{bp}$ of pBR322 DNA (hopefully innocuous DNA) was inserted at positions -55 and -226 [designated hMTlacO(-55)-S-CAT and hMTlacO(-226)-S-CAT]. The purpose of these latter two constructs was to test the effect of binding of a lac repressor to the operator when direct protein-protein contacts of bound repressor with adjacent regulatory proteins was not possible without looping or bending.

Effect of the lacO inserts on expression in the absence of repressor. Before study of repression by the lac repressor and derepression by IPTG, it was necessary to examine the effects of the lacO inserts at the several sites on expression in the absence of repressor. These experiments were carried out in XC and Rat 2 cell lines, both of which express reasonable levels of glucocorticoid receptor and thus permit glucocorticoid induction of the hMT promoter. The results were not cell line dependent, and only results for XC are presented in detail.

As described in Materials and Methods, the transfection protocols were carried out four times independently, with carefully monitored amounts of DNA and numbers of cells, and protein assays of cell lysates were performed to ensure that equal amounts of extract were used for all CAT assays. All measurements were within the linear activity range for the assay. These procedures were adopted to achieve satisfactory reproducibility and linearity of the data.

The CAT assays for transfected XC cells are shown in Fig. 2 and summarized in Table 1 . Even in the absence of repressor protein, insertion of the $30-\mathrm{bp}$ lacO sequence at 


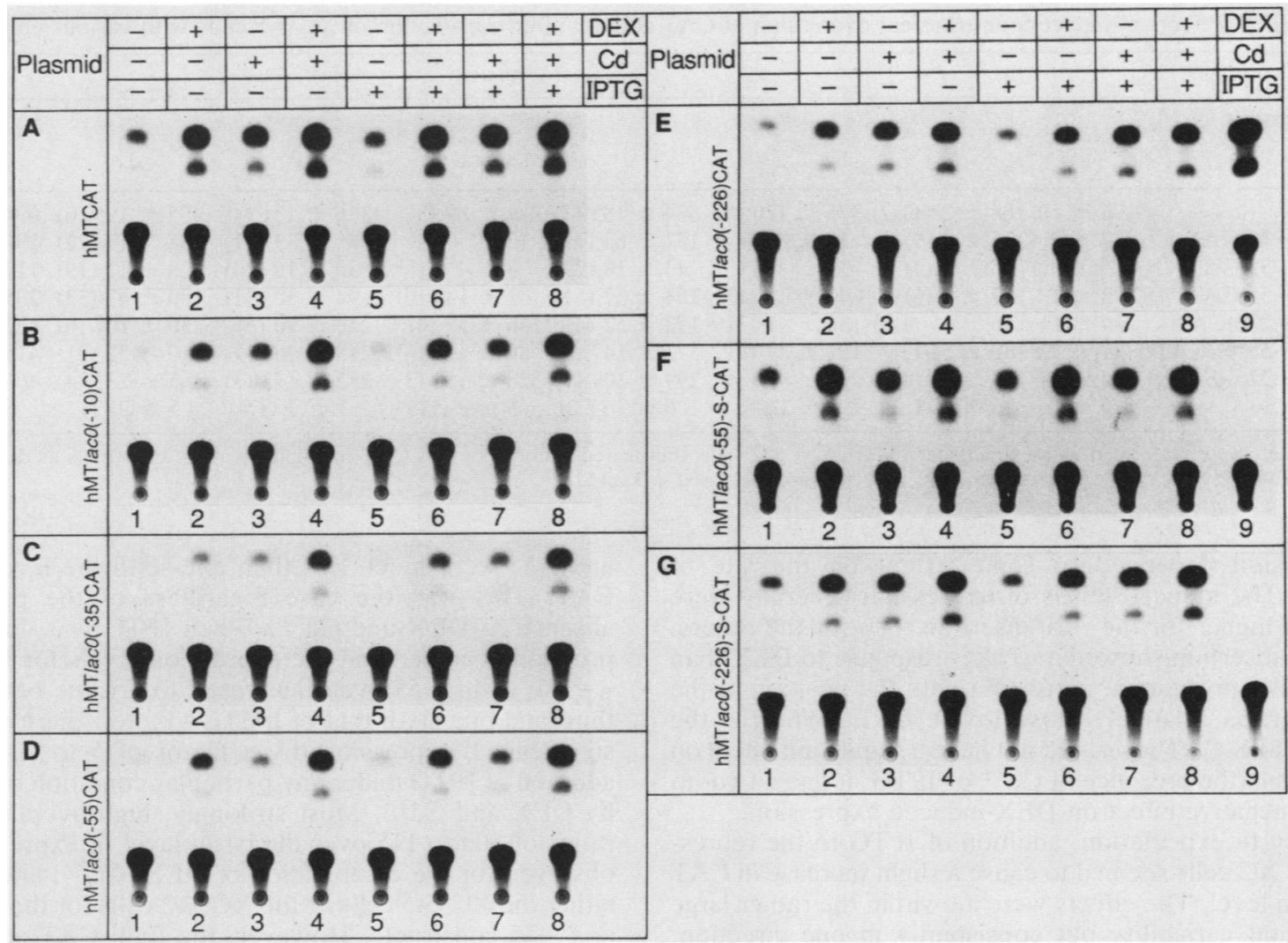

FIG. 2. Repression and induction of CAT activity after transient transfection with various constructs in XC cells (repressor negative). Transient transfection experiments were carried out with the CAT-containing plasmid constructs listed in Table 1. Plates (60-mm diameter) of ca. $10^{6} \mathrm{XC}$ cells were transfected with $4 \mu \mathrm{g}$ (at a $2-\mu \mathrm{g} / \mathrm{ml}$ final concentration) of plasmid DNA, as indicated in each panel, by using the DEAE-dextran protocol. After transfection, cells were cultured where indicated in medium with (+) or without $(-)$ extracellular inducers $\left(\mathrm{DEX}, \mathrm{Cd}^{2+}\right.$ ion, and/or IPTG) for $48 \mathrm{~h}$ before being harvested for determination of CAT activity. Aliquots of extracts containing $100 \mu \mathrm{g}$ of protein were adjusted to a final volume of $100 \mu$ and assayed in parallel for CAT activity. CAT assays were performed as described in the footnote to Table 1 and Materials and Methods.

sites $-10,-35$, and -55 reduced the uninduced (basal) level of expression by a factor of about 10 compared with the level of parental promoter in hMTCAT. At the well-upstream position, -226 , the uninduced level of expression was about one-half that of hMTCAT. Uninduced levels of CAT expression for the larger inserts of the -S-CAT series at -55 or -226 were not significantly lower than those of the parental promoter.
For hMTCAT, we observed $9 \pm 3$ - and a $5 \pm 2$-fold induction by $\mathrm{DEX}$ and $\mathrm{Cd}^{2+}$ ions, respectively, over the basal levels whereas the combined effect of DEX plus $\mathrm{Cd}^{2+}$ produced a $13 \pm 6$-fold induction. Thus, the combined effects of the two inducers were greater than the effect of either alone but much less than the product of the two induction ratios.

The effects of the short lac $O$ insertions on induced levels

TABLE 1. Effects of inducers on transient expression of CAT activity after transfection of XC cells with various constructs ${ }^{a}$

\begin{tabular}{|c|c|c|c|c|c|c|c|c|}
\hline \multirow{3}{*}{ Construct } & \multicolumn{8}{|c|}{ CAT activity } \\
\hline & - & - & + & + & $\overline{-}$ & - & + & + \\
\hline & - & + & _ & + & - & + & - & + \\
\hline hMTCAT & $33 \pm 10$ & $39 \pm 10(1.2)$ & $281 \pm 86(9)$ & $381 \pm 98(12)$ & $148 \pm 52(5)$ & $223 \pm 63(7)$ & $441 \pm 200(13)$ & $506 \pm 206(15)$ \\
\hline hMTlac $O(-10)$ CAT & $5 \pm 2$ & $7 \pm 2(1.4)$ & $76 \pm 52(15)$ & $102 \pm 37(20)$ & $44 \pm 26$ & $72 \pm 45(14)$ & $188 \pm 126(38)$ & $217 \pm 122(43)$ \\
\hline hMTlac $O(-35)$ CAT & \pm 1 & $3.5 \pm 1(1.2)$ & $19 \pm 12(6)$ & $31 \pm 15(10)$ & $15 \pm 9(5)$ & $27 \pm 13(9)$ & $65 \pm 46(22)$ & $94 \pm 50(31)$ \\
\hline hMTlacO(-55)CAT & $4 \pm 1$ & $6 \pm 2(1.5)$ & $59 \pm 31(15)$ & $83 \pm 46(21)$ & $32 \pm 19(8)$ & $46 \pm 22(12)$ & $170 \pm 113(43)$ & $202 \pm 122(51)$ \\
\hline hMTlac $O(-226)$ CAT & $16 \pm 6$ & $21 \pm 7(1.3)$ & $59 \pm 19(4)$ & $89 \pm 23(6)$ & $78 \pm 19(5)$ & $106 \pm 21(7)$ & $160 \pm 77(10)$ & $212 \pm 64(13)$ \\
\hline hMTlacO(-55)-S-CAT & $26 \pm 7$ & $31 \pm 10(1.2)$ & $128 \pm 19(5)$ & $168 \pm 54(6)$ & $71 \pm 13(3)$ & $77 \pm 25$ & $221 \pm 25(9)$ & $212 \pm 26(8)$ \\
\hline hMTlac $O(-226)-S-C A T$ & $30 \pm 11$ & $38 \pm 12(1.3)$ & $94 \pm 16(3)$ & $113 \pm 23(4)$ & $140 \pm 44(5)$ & $153 \pm 48(5)$ & $217 \pm 62(7)$ & $258 \pm 65(9)$ \\
\hline pUCCAT & $2 \pm 0.5$ & $2 \pm 1(1)$ & $2 \pm 1(1)$ & $2.5 \pm 1(1.3)$ & $1.6 \pm 0.5(1)$ & $2.2 \pm 1(1.1)$ & $2.3 \pm 1(1.2)$ & $2.5 \pm 1(1.3)$ \\
\hline
\end{tabular}

${ }^{a}$ Plates $(60-\mathrm{mm}$ diameter) of XC cells were transfected with the indicated CAT-containing plasmid constructs. Twelve hours after transfection, the cells were incubated as indicated in medium with (+) or without (-) various inducers (DEX [top row of symbols], Cd ${ }^{2+}$ [middle row], and/or IPTG [bottom row]) for 48 $\mathrm{h}$ before being harvested and assayed for CAT activity as described in Materials and Methods. Activities in inducer-treated cells were divided by those in untreated cells to yield the fold induction, which is indicated in parentheses. 
TABLE 2. Effects of inducers on transient expression of CAT activity after transfection of XC35-5 cells with various constructs ${ }^{a}$

\begin{tabular}{lcccccccc}
\hline & \multicolumn{7}{c}{ CAT activity } \\
\cline { 2 - 9 } Construct & - & - & + & + & - & - & + \\
& - & - & - & - & + & + & + \\
& - & + & - & + & - & + & + \\
\hline hMTCAT & $76 \pm 10$ & $88 \pm 23(1.2)$ & $375 \pm 120(5)$ & $534 \pm 185(7)$ & $237 \pm 89(3)$ & $336 \pm 131(4)$ & $475 \pm 195(6)$ & $694 \pm 263(9)$ \\
hMTlacO(-10)CAT & $1.7 \pm 0.4$ & $15 \pm 5(9)$ & $16 \pm 8(9)$ & $131 \pm 62(77)$ & $12 \pm 5(7)$ & $86 \pm 33(51)$ & $38 \pm 17(22)$ & $196 \pm 91(115)$ \\
hMTlacO(-35)CAT & $1.5 \pm 0.5$ & $6 \pm 2(4)$ & $10 \pm 4(7)$ & $43 \pm 18(29)$ & $8 \pm 4(5)$ & $30 \pm 16(20)$ & $28 \pm 12(19)$ & $119 \pm 56(79)$ \\
hMTlacO(-55)CAT & $3 \pm 1$ & $17 \pm 6(6)$ & $40 \pm 14(13)$ & $154 \pm 57(51)$ & $31 \pm 14(10)$ & $94 \pm 30(31)$ & $100 \pm 47(33)$ & $295 \pm 118(98)$ \\
hMTlacO(-226)CAT & $44 \pm 11$ & $56 \pm 15(1.3)$ & $134 \pm 31(3)$ & $172 \pm 52(4)$ & $156 \pm 57(4)$ & $218 \pm 90(5)$ & $250 \pm 107(6)$ & $325 \pm 136(7)$ \\
hMTlacO(-55)-S-CAT & $71 \pm 22$ & $180 \pm 51(3)$ & $151 \pm 57(2)$ & $371 \pm 147(5)$ & $89 \pm 11(1.3)$ & $243 \pm 96(3)$ & $150 \pm 52(2)$ & $415 \pm 180(6)$ \\
hMTlacO(-226)-S-CAT $114 \pm 34$ & $115 \pm 36(1)$ & $294 \pm 98(3)$ & $299 \pm 109(3)$ & $328 \pm 156(3)$ & $285 \pm 133(3)$ & $465 \pm 233(4)$ & $466 \pm 191(4)$ \\
pUCCAT & $5 \pm 1$ & $6 \pm 2(1.2)$ & $4 \pm 1(1)$ & $6 \pm 3(1.2)$ & $5 \pm 2(1)$ & $7 \pm 3(1.4)$ & $5 \pm 2(1)$ & $6 \pm 2(1.2)$ \\
\hline
\end{tabular}

${ }^{a}$ CAT assays were performed with extracts derived from XC35-5 cells transfected with the various CAT-containing plasmid constructs as described in the footnote to Table 1. Specific CAT activity and fold induction are expressed in Table 1.

of expression depended to some extent on the site of insertion. The induced levels of expression generally were somewhat higher for the -10 insertion than for the others. The -226 insertion showed a weaker response to DEX than did the other promoters, consistent with the position of the -226 insertion relatively close to the GRE. Whereas the lac $O(-226)-S-C A T$ insert did not have a significant effect on expression in the presence of $\mathrm{Cd}^{2+}$ or IPTG, it had a two- to threefold negative effect on DEX-induced expression.

Contrary to expectation, addition of IPTG to the repressor-minus XC cells seemed to cause a slight increase in CAT expression level. The effects were all within the rather large experimental variability but consistently in one direction, suggesting the existence of a small nonspecific effect.

Induction and IPTG derepression of CAT expression in repressor-plus cells. Tables 2 and 3 summarize the CAT activity results for $\mathrm{XC} 35-5$ cells (expressing the wild-type repressor) and XC36- 2 cells (expressing the modified repressor with a karyophilic sequence). Generally, there was very little difference between the results for the wild-type and modified (NLS-containing) repressor, and we will focus on the former (Fig. 3 and Table 2).

Figure 3 is a bar graph with a visual presentation of the data in Table 2. The data are grouped in sets of four to compare the effect of IPTG treatment on a construct containing a lac $O$ insert with the effect for the hMTCAT construct that does not contain a lac $O$ insert in the presence or absence of DEX and $\mathrm{Cd}^{2+}$. To simplify visual presentation, the expression levels of hMTCAT are divided by 6 .

In the absence of IPTG in these repressor-positive cells, the CAT expression levels with the lac $O$ inserts at $-10,-35$, and -55 were much less than one-sixth the level for hMT CAT. This was the case regardless of the presence or absence of DEX and $\mathrm{Cd}^{2+}$. When IPTG was added, derepression occurred and the expression levels for $\operatorname{lac} O(-10)$, $-(-35)$, and $-(-55)$ were increased to a value between onethird and one-sixth that of hMTCAT; i.e., there was a very significant derepression (by a factor of 5 to 10) upon the addition of IPTG under any particular condition of induction by $\mathrm{DEX}$ and $\mathrm{Cd}^{2+}$. Most strikingly, high overall induction ratios of 100 to 115 over the basal level of expression were observed for the combination of DEX, $\mathrm{Cd}^{2+}$, and IPTG for either the XC35-5 cells or the XC36-2 cells for the $-10,-35$, and -55 constructs. However, the total CAT activity was still three- to fourfold higher in hMTCAT than in any of the fully induced $l a c O$ inserts, although the induction ratios were much less marked for hMTCAT.

The effects of adding IPTG on expression by the lacO $(-226)$ construct were quite small (Fig. 3). As noted earlier, the insert reduced expression levels by a factor of slightly less than 2 for the uninduced and plus- $\mathrm{Cd}^{2+}$ conditions and by about 3 for any plus-DEX conditions, but these ratios were unchanged when IPTG was added. Expression levels for the long inserts, $(-55)-S-C A T$ and $(-226)-S-C A T$, were similar to those for hMTCAT and not significantly influenced by IPTG (Tables 1 to 3 ).

Stable transfectants give similar results. Stable transfectants of the hMTlac $O(-55) \mathrm{CAT}$ and hMTCAT constructs were prepared by cotransformation of XC36-2 cells with an $\mathrm{hmB}$ gene as the selectable marker as described in Materials and Methods. Stable transfectants were selected in media supplemented with hmB. After 8 days in selective medium,

TABLE 3. Effects of inducers on transient expression of CAT activity after transfection of XC36-2 cells with various constructs ${ }^{a}$

\begin{tabular}{|c|c|c|c|c|c|c|c|c|}
\hline \multirow{4}{*}{ Construct } & \multicolumn{8}{|c|}{ CAT activity } \\
\hline & - & - & + & + & - & - & + & + \\
\hline & - & - & - & - & + & + & + & + \\
\hline & - & + & - & + & - & + & - & + \\
\hline hMTCAT & $67 \pm 12$ & $84 \pm 20(1.3)$ & $383 \pm 84(6)$ & $560 \pm 127(8)$ & $183 \pm 60$ & $284 \pm 100(4)$ & $461 \pm 116(7)$ & $639 \pm 145(10)$ \\
\hline hMTlac $O(-10)$ CAT & $1.5 \pm 0.5$ & $14 \pm 3(9)$ & $11 \pm 4(7)$ & $94 \pm 18(63)$ & $7 \pm 3(5)$ & $66 \pm 14(44)$ & $24 \pm 9(16)$ & $170 \pm 22$ \\
\hline hMTlac $O(-35)$ CAT & $1.5 \pm 0.5$ & $6 \pm 2(4)$ & $7 \pm 2(5)$ & $32 \pm 6(21)$ & $6 \pm 2(4)$ & $24 \pm 3(16)$ & $24 \pm 8(16)$ & $100 \pm 21(67)$ \\
\hline hMTlacO(-55)CAT & $2.2 \pm 0.4$ & $13 \pm 2(6)$ & $25 \pm 6(11)$ & $131 \pm 32(60)$ & $21 \pm 6(10)$ & $68 \pm 16(31)$ & $70 \pm 16(32)$ & $243 \pm 21(110)$ \\
\hline hMTlac $O(-226)$ CAT & $44 \pm 17$ & $47 \pm 10(1)$ & $114 \pm 33(3)$ & $147 \pm 29(3)$ & $177 \pm 38(4)$ & $201 \pm 42(5)$ & $230 \pm 55(5)$ & $314 \pm 45(7)$ \\
\hline hMTlacO(-55)-S-CAT & $54 \pm 13$ & $125 \pm 18(2.3)$ & $148 \pm 55(3)$ & $337 \pm 106(6)$ & $69 \pm 15(1.3)$ & $193 \pm 43(4)$ & $136 \pm 37(3)$ & $412 \pm 103(8)$ \\
\hline hMTlacO(-226)-S-CAT & $78 \pm 13$ & $72 \pm 12(1)$ & $228 \pm 41(3)$ & $216 \pm 35(3)$ & $217 \pm 48(3)$ & $199 \pm 34(3)$ & $344 \pm 100(4)$ & $362 \pm 87(5)$ \\
\hline pUCCAT & $4 \pm 1$ & $4.5 \pm 1(1)$ & $4 \pm 1(1)$ & $4 \pm 1(1)$ & $3.5 \pm 0.5(1)$ & $4.5 \pm 0.5(1)$ & $4 \pm 1(1)$ & $4 \pm 0.5$ \\
\hline
\end{tabular}

${ }^{a}$ CAT assays were performed with extracts derived from $\mathrm{XC} 36-2$ cells transfected with the various CAT-containing plasmid constructs as described in the footnote to Table 1 . Specific CAT activity and fold induction are expressed as in Table 1. 

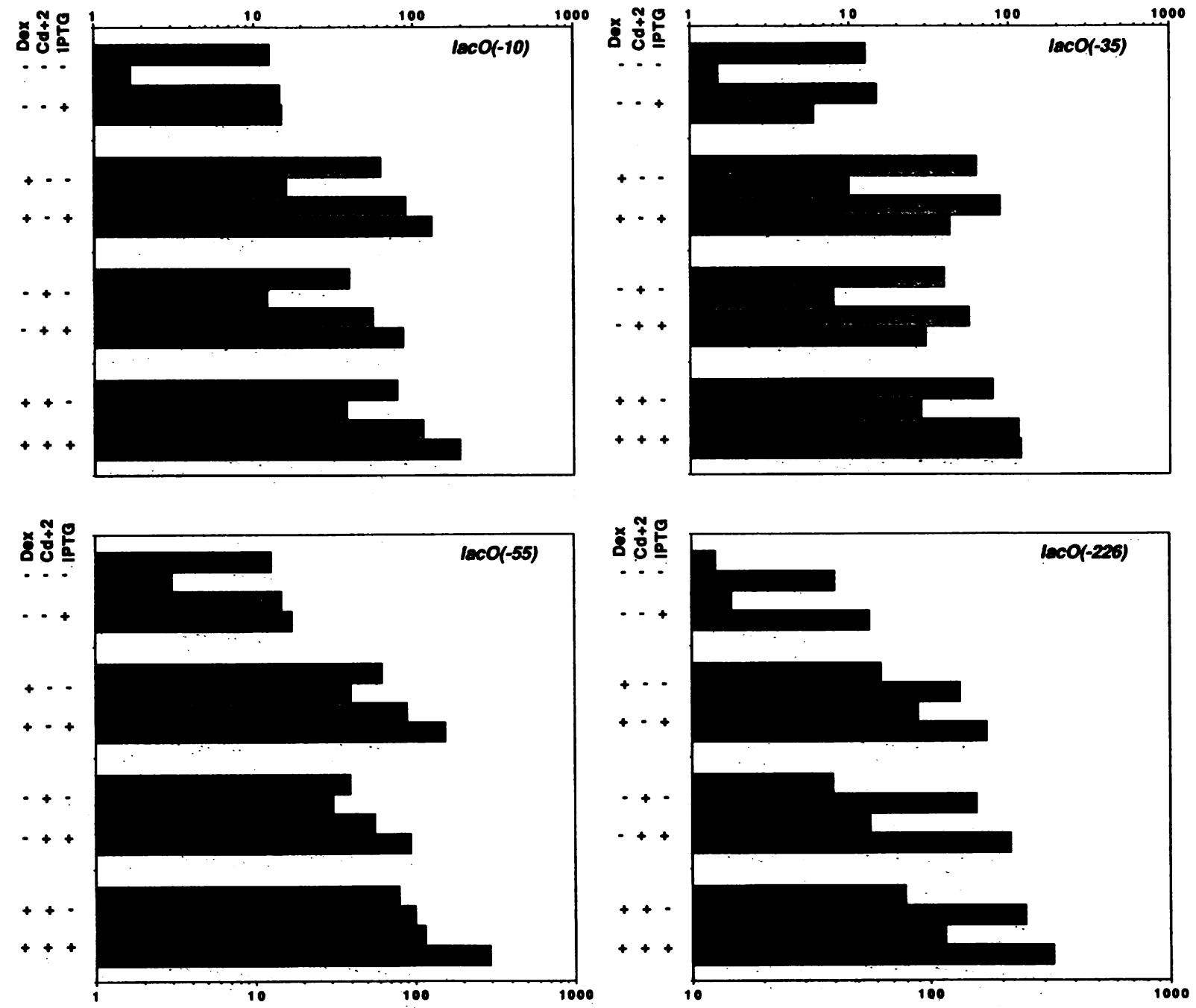

FIG. 3. Relative CAT expression levels of constructs with and without a lac $O$ insert in cells expressing the lac repressor. Symbols: $\square$, indicated lacO insertions; 誹, hMTCAT construct (no lac $O$ insert). Values are plotted on a $\log _{10}$ scale. The values for hMTACAT have been divided by 6. Data are from XC35-5 cells (see Table 2).

four hmB-resistant colonies were isolated as single clones for each construct, and the remaining transformants (ca. 80 to 100 colonies) were pooled. These isolates were expanded as needed and then tested for CAT expression levels under various conditions. Southern blot analysis showed that the copy number of the integrated CAT sequence was 10 to 20. The effects of the lac $O$ insert in XC cells and of several inducers, including IPTG, were essentially the same as for the transient expression experiments (Table 4).

\section{DISCUSSION}

For an inducible gene such as the hMTCAT gene, the value of the basal level of expression in the absence of any added inducers will depend on the level of metal ion, hormone, and other inducers in the cell culture medium used. For stable transfectants, it will also vary with the integration site and structure of the integrated DNA. Thus, the basal level of expression is likely to vary in the hands of different experimenters. For this reason, the total induction ratios reported (e.g., in Table 2) as the ratios of the CAT enzyme level in the presence and absence of DEX, $\mathrm{Cd}^{2+}$, and IPTG for any given construction and cell type are likely to be different when tested in different laboratories.
Nevertheless, the major result reported here is that induction ratios of about 100 were measured for the $-10,-35$, and -55 inserts. In a practical sense, the basic objective of this study, namely, to combine positive induction of gene expression due to the endogenous hormone and metal ion-responsive sequences of the metallothionein gene with an additional level of control by using the lac repressor and operator, has been met.

One striking and unexpected result of this work was the marked (ca. 10-fold) reduction of expression due to the lac $O$ insert at $-10,-35,-55$ in the $\mathrm{XC}$ repressor-negative cells. In our previous study, the effects of a single lac $O$ insert into a similar position in the promoter used were at most $50 \%$, depending on the point of insertion (15). These results were in a different cell type ( $\left(t k^{-}\right)$, with a 40-bp natural lacO sequence instead of the symmetric 30-bp lac $O$ insert used here, and with a different promoter (a hybrid Moloney sarcoma virus-SV40 promoter). Thus, precise comparisons are impossible; nevertheless, the much greater inhibitory effect of the symmetric lacO insertion in the study described here is striking. Possible mechanisms for this result are discussed below.

We note parenthetically that even in $\mathrm{XC}$ cells, the 
TABLE 4. Effects of inducers on stable expression of CAT activity in cell clones of XC36-2 cells transfected with various constructs ${ }^{a}$

\begin{tabular}{|c|c|c|c|c|c|c|c|c|}
\hline \multirow[b]{2}{*}{ Constructs } & \multicolumn{8}{|c|}{ CAT activity } \\
\hline & $\begin{array}{l}- \\
- \\
-\end{array}$ & $\begin{array}{l}- \\
- \\
+\end{array}$ & $\begin{array}{l}+ \\
- \\
-\end{array}$ & $\begin{array}{l}+ \\
- \\
+\end{array}$ & $\begin{array}{l}- \\
+ \\
-\end{array}$ & $\begin{array}{l}- \\
+ \\
+\end{array}$ & $\begin{array}{l}+ \\
+ \\
-\end{array}$ & $\begin{array}{l}+ \\
+ \\
+\end{array}$ \\
\hline $\begin{array}{l}\text { hMTCAT (pooled } \\
\text { clones) }\end{array}$ & $264 \pm 5$ & $333 \pm 14(1.2)$ & $1,344 \pm 133(5)$ & $1,414 \pm 42(5)$ & $593 \pm 15(2)$ & $858 \pm 32(3)$ & $1,082 \pm 81(4)$ & $1,202 \pm 10(5)$ \\
\hline $\begin{array}{l}\text { hMTlac }(-55) \text { CAT } \\
\text { (pooled clones) }\end{array}$ & $3 \pm 0.5$ & $32 \pm 10(11)$ & $39 \pm 8(13)$ & $168 \pm 14(48)$ & $37 \pm 2(12)$ & $140 \pm 3(40)$ & $108 \pm 4(36)$ & $335 \pm 13(96)$ \\
\hline $\begin{array}{l}\text { hMTCAT (single } \\
\text { clones) }\end{array}$ & $235 \pm 10$ & $355 \pm 21(1.5)$ & $1,378 \pm 11(6)$ & $1,399 \pm 9(6)$ & $474 \pm 19(2)$ & $717 \pm 36(3)$ & $1,182 \pm 16(5)$ & $1,238 \pm 34(5)$ \\
\hline $\begin{array}{l}\text { hMTlac } O(-55) \text { CAT } \\
\text { (single clones) }\end{array}$ & $5 \pm 1$ & $49 \pm 4(10)$ & $67 \pm 6(13)$ & $235 \pm 13(47)$ & $48 \pm 4(10)$ & $122 \pm 8(24)$ & $171 \pm 13(34)$ & $385 \pm 31(77)$ \\
\hline
\end{tabular}

${ }^{a}$ XC36-2 cells were transfected with CAT-containing plasmids and plasmid pY3, which carries the hmB phosphotransferase gene, and stable cotransfectants were isolated as described in Materials and Methods. Specific CAT activity and fold induction are expressed as in Table 1.

hMTlac $O(-10) \mathrm{CAT}$ construct gave rather good induction ratios of 38 for DEX plus $\mathrm{Cd}^{2+}$ and 43 for DEX plus $\mathrm{Cd}^{2+}$ plus IPTG. If similar results obtain with other reporter genes and the same promoter, this construction could be useful for studies in which it is impractical to prepare a lac repressorpositive cell line.

The results for induction ratios with cells expressing the modified repressor containing the SV40 karyophilic sequence were about the same as those for the wild-type repressor, probably because, as reported elsewhere ( $\mathrm{Hu}$ and Davidson, in press), the effective concentration of functional repressor in the nucleus was about fourfeld less for the mutant than for the wild-type repressor. The XC35-5 line expressed ca. $8 \times 10^{5}$ monomer subunits per cell, all of which were assembled into functional tetramers, but only 2 $\times 10^{4}$ of these were localized in the nucleus ( $\mathrm{Hu}$ and Davidson, in press). The XC36-2 cells expressed $1.6 \times 10^{5}$ monomers per cell, all of which were in the nucleus. However, the effective concentration of functional tetramers, as assayed by lac $O$ binding in vitro in the presence of an excess of nonspecific DNA, was only $5 \times 10^{3}$ per nucleus. The reason for this finding is either inefficient assembly of monomer peptide subunits into tetramers or a reduced affinity of the modified, more positively charged repressor for the operator relative to nonspecific DNA binding ( $\mathrm{Hu}$ and Davidson, in press). However, the somewhat disappointing result with this particular modified repressor does not necessatrily mean that other constructs, with this or some other karyophilic sequence inserted at different points in the lac repressor, will not be more effective. A determination of the full three-dimensional structure of the repressor will be useful for this purpose (31). Furthermore, NLSs with only three or four basic amino acids are known (8) and might be more effective than the $\mathrm{T}$-antigen signal for fusing to a functional lac repressor.

While this report was under review, a description of an interesting related but alternative approach based on the lac operator-repressor interaction appeared (22). Labow et al. (22) added the SV40 T-antigen NLS to the amino termini of several lacI gene constructs. They observed that this signal directed the lacI-containing gene product to the nucleus, just as did the carboxy-terminal NLS studied by us ( $\mathrm{Hu}$ and Davidson, in press). Most importantly, these authors made a fusion protein of the lac repressor with the carboxy-terminal (100-amino-acid) transactivating domain of the herpes simplex virus virion protein 16 . Cotransfection of this construct with a CAT vector containing an enhancerless SV40 promoter into which one or multiple lac operator elements had been inserted resulted in very high levels of expression due to transactivation.

The method described here was designed to provide a high level of induction of a particular transfected gene in a cell by simultaneous induction with $\mathrm{Cd}^{2+}$ and/or glucocorticoid and derepression by IPTG. This is important when the transfected gene product is toxic to the cell or generally when one wishes to see the effect of change in gene expression in an otherwise constant cell background. In the system described by Labow et al. (22), the only level of control is by IPTG-induced dissociation of the transactivator from the lac $O$ segment. The induction ratios reported by Labow et al. do not appear to be quite as high as those reported by us; however, the maximum level of expression achieved appears to be much higher. In the method of Labow et al., it is necessary to maintain the cells in the presence of IPTG to keep the gene in an off state, whereas in our method, IPTG is added to cause derepression.

Effects of the lacO insertion at different positions and implications as to the mechanism of regulatory controls. It is of interest to consider the dependence of the results on the site of insertion of the lac $O$ segment both from the practical viewpoint of engineering effective control systems and because of the insights that these results may provide as to the mechanisms of regulatory protein interactions at a promoter.

In general, sequence-specific transcription factors activate or repress transcription of a gene by binding to cis sequence elements in the neighborhood of the gene. Many of these elements are within several hundred base pairs of the gene, but some (enhancers) can act over greater distances and in an orientation-independent manner. The bound transcription factors interact with each other and with RNA polymerase in ways that are not well understood to control the rate of initiation of transcription (for reviews, see references 27, 30, 32,33 , and 36).

Proteins bound to neighboring cis sequence segments presumably interact by direct protein-protein contact. The occurrence of flexibility and partial bending of the DNA chain to allow protein-protein contact is suggested by the observation that separating nearby elements by spacers of length 5 or $15 \mathrm{bp}$ decreases transcription more than does insertion of spacer DNA of 10 or $21 \mathrm{bp} \mathrm{(39).}$

There are two general classes of proposed mechanisms for the action of transcription factors that bind at more distant enhancer elements. One is action through space by looping of DNA or chromatin, thus permitting protein-protein contact $(32,36)$. The alternative mechanism is action through the chain, possibly because the enhancer serves as an RNA 
polymerase entry site, from which the polymerase slides along the DNA to the transcription start point (28) or possibly because the enhancer-binding protein initiates DNA unwinding, which then somehow propagates down the chain. New experimental evidence (29) as well as the consensus of current opinion favor the looping model.

In this study, the lacO was inserted into several sites in the promoter region of the hMT-II $\mathrm{A}_{\mathrm{A}}$ gene. The positions of the known cis-acting elements, as summarized in reference 19 , are shown in Fig. 1.

(i) The $30 \pm 4-b p$ lac $O$ insertion has a marked negative effect on transcription. Because of the nature of the DNA manipulations, the insertion at the $S c a$ I site $(-10)$ is exactly $30 \mathrm{bp}$ in length; at the XhoI site $(-35)$ it is $34 \mathrm{bp}$, and at the SphI sites (either -55 or -226 ) it is $26 \mathrm{bp}$. The depression by 10 -fold of constitutive transcription levels for the insertions at $-10,-35$, and -55 (Table 1 ) is much greater than the $50 \%$ effect that we observed in our earlier work (15) for insertions of the native lac $O$ 40-bp sequence into a Moloney sarcoma virus-SV40-based promoter. It would be necessary to test some other $30 \pm 4$-bp spacer DNA insertions to determine whether the specific symmetric lac $O$ sequence has an unusual inhibiting effect on gene expression even in the absence of repressor. The observation that the insertion at -226 , a position that seems to be well separated from all known control sequences, has a twofold inhibiting effect encourages the speculation that there is a specific effect, perhaps due to adventitious eucaryotic protein binding, of the 30-bp lac $O$ sequence.

(ii) Insertions at $\mathbf{- 2 2 6}$. In repressor-positive cells (Tables 2 and 3), the insertion of lacO plus spacer DNA at -226 , just downstream of the GRE, had only a ca. 33\% negative effect on glucocorticoid-induced expression; the 30-bp insertion without spacer at this position reduced DEX-induced expression by ca. $66 \%$. If one assumes that repressor binding would block action through the chain, these results favor the looping model for action at a distance.

(iii) Insertions at $\mathbf{- 5 5}$. The lac $O$ insertion at -55 lies very close to (and just downstream of) the Sp1-binding site (GC box in Fig. 1) and close to (and just upstream of) MRE1 but more distant from MRE2, -3 , or -4 . lac repressor bound at this site had a three- to fivefold negative effect on expression in the presence of DEX (as judged by the effect of adding IPTG) and a three- to fourfold negative effect in the presence of $\mathrm{Cd}^{2+}$ (Tables 2 and 3). The effect in the presence of DEX suggests that one of the factors with which the glucocorticoid receptor bound at the GRE must interact in order to stimulate transcription is Sp1 bound at the GC box. We then assume that bound lac repressor at -55 prevents or modifies the binding of Sp1 to the GC box. Evidence for a synergistic interaction of the bound glucocorticoid receptor with $\mathrm{Sp} 1$ and other factors has been presented elsewhere $(35,37)$. Similarly, the fact that lac repressor bound at the -55 site has a three- to fivefold negative effect on $\mathrm{Cd}^{2+}$-induced expression suggests that the MRE-bound factors also interact with $\mathrm{Sp1}$. lac repressor bound to the lacO insert with spacer DNA at -55 had essentially no effect on expression in the presence of $\mathrm{DEX}$ or $\mathrm{Cd}^{2+}$. It would thus appear that looping mechanisms are effective in permitting interactions of all of the needed factors despite the presence of lac repressor in the center of the long insertion. This model is depicted in Fig. 4.

(iv) Insertions at $\mathbf{- 3 5}$ and $\mathbf{- 1 0}$. The insertions at -35 and -10 lie between MRE1 and the TATA site (Fig. 1) and between the latter and the transcription start point, respectively. In repressor-positive cells, the greatest effects on

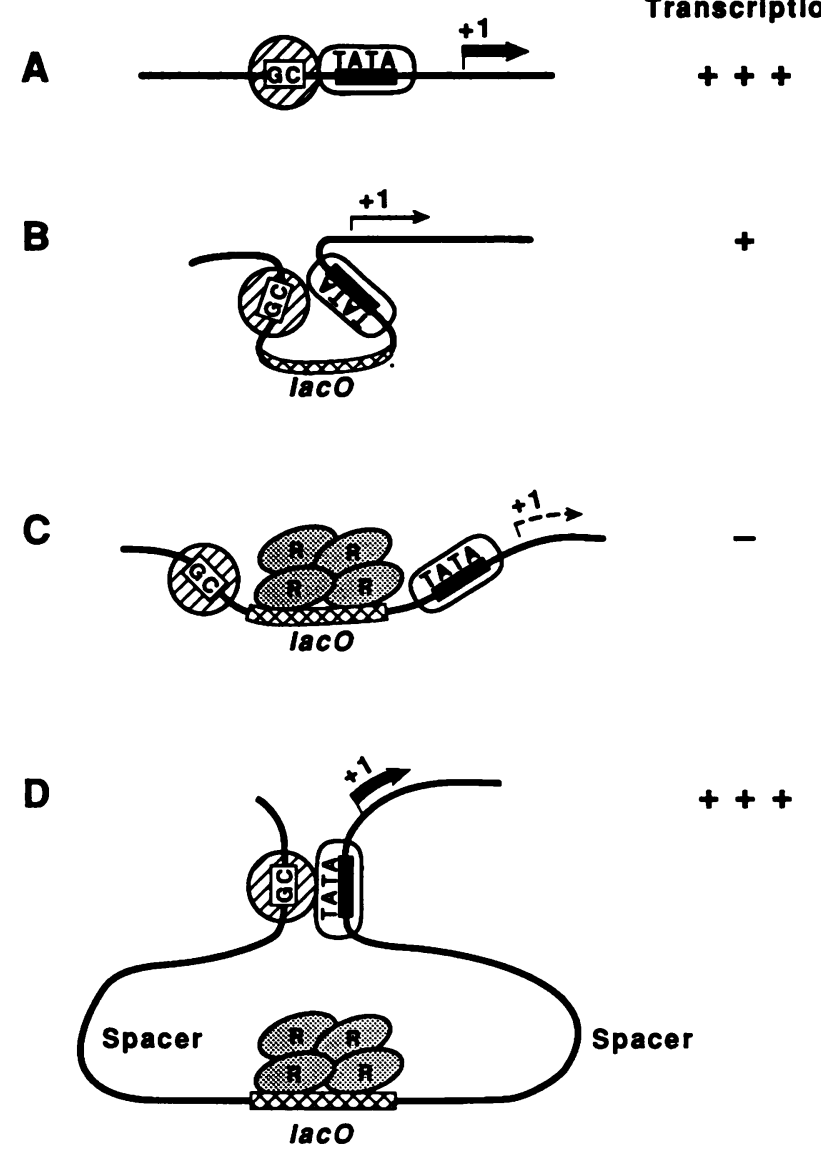

FIG. 4. Schematic model for transcriptional activation and repression by proximal promoter factors in the absence or presence of lac repressor. The GC box-binding factor $\mathrm{Spl}(\mathrm{GC})$, the TATA boxbinding factor complex (TATA), and the lac repressor tetramers (R) are indicated. A solid arrow indicates active transcription from the transcription start site $(+1)$; a dashed arrow indicates that transcription is not active.

expression in the absence of IPTG were observed for these two insertions (Tables 2 and 3). Effects due to the -35 insertion appeared to be somewhat greater than for the -10 insertion. For the latter case, overall induction ratios of ca. 100 were achieved in the presence of IPTG plus DEX plus $\mathrm{Cd}^{2+}$.

We suggest that repressor at -35 interferes with binding of protein to the TATA box, with the interaction of upstream proteins with the TATA box binding protein, or with both. Repressor binding at the -10 insert may interfere directly with the TATA box site, but it is closer to the transcription start point and may interfere primarily with binding of an RNA polymerase complex at the transcription start point (7).

Overall, our results are consistent with the view that two transcription factors bound at their respective specific sites can interact by direct contact if the specific cis sequences are adjacent, by gentle bending if the cis sequences are separated by short (10- to 50 -bp, perhaps) spacer DNA, or by looping for larger spacings. Repressor bound to a short lacO insertion can interfere with interactions involving a transcription factor that is bound very close to the lac $O$ sequence. However, when the lac $O$ sequence is flanked by long spacer DNA (190 bp in our case), interactions by looping are not inhibited by bound repressor. This general 
view should serve as a guide in designing other constructions for the control of gene expression.

\section{ACKNOWLEDGMENTS}

We are grateful to Michael Karin (University of California, San Diego) for generously providing a $-2865^{\prime}$ deletion mutant of the

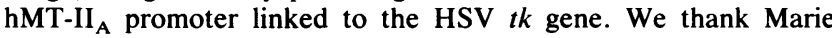
Krempin for assistance with cell cultures.

This work was supported by a grant from Amgen, Inc., and by a Public Health Service research grant from the National Institutes of Health.

\section{LITERATURE CITED}

1. Angel, P., M. Imagawa, R. Chiu, B. Stein, R. J. Imbra, H. J. Rahmsdorf, C. Jonat, P. Herrlich, and M. Karin. 1987. Phorbol ester-inducible genes contain a common cis element recognized by a TPA-modulated trans-acting factor. Cell 49:729-739.

2. Biggin, M. D., T. J. Gibson, and G. F. Hong. 1983. Buffer gradient gels and $35 \mathrm{~S}$ label as an aid to rapid DNA sequence determination. Proc. Natl. Acad. Sci. USA 80:3963-3965.

3. Blochlinger, K., and H. Diggelmann. 1984. Hygromycin B phosphotransferase as a selectable marker for DNA transfer experiments with higher eucaryotic cells. Mol. Cell. Biol. 4:29292931.

4. Bond-Matthews, B., and N. Davidson. 1988. Transcription from each of the Drosophila act5C leader exons is driven by a separate functional promoter. Gene 62:289-300.

5. Bradford, M. 1976. A rapid and sensitive method for the quantitation of microgram quantities of protein utilizing the principle of protein-dye binding. Anal. Biochem. 72:248-254.

6. Brown, M., J. Figge, U. Hansen, C. Wright, K. Jeang, G. Khoury, D. M. Livingston, and T. M. Roberts. 1987. lac repressor can regulate expression from a hybrid SV40 early promoter containing a lac operator in animal cells. Cell 49:603-612.

7. Buratowski, S., S. Hahn, L. Guarente, and P. A. Sharp. 1989. Five intermediate complexes in transcription initiation by RNA polymerase II. Cell 56:549-561.

8. Chelsky, D., R. Ralph, and G. Jonak. 1989. Sequence requirements for synthetic peptide-mediated translocation to the nucleus. Mol. Cell. Biol. 9:2487-2492.

9. Deuschle, U., R. Pepperkok, F. Wang, T. J. Giordano, W. T. McAllister, W. Ansorge, and H. Bujard. 1989. Regulated expression of foreign genes in mammalian cells under the control of coliphage T3 RNA polymerase and lac repressor. Proc. Natl. Acad. Sci. USA 86:5400-5404.

10. Felgner, P. L., T. R. Gadek, M. Holm, R. Roman, H. W. Chan, M. Wenz, J. P. Northrop, G. M. Ringold, and M. Danielsen. 1987. Lipofection: a highly efficient, lipid-mediated DNA-transfection procedure. Proc. Natl. Acad. Sci. USA 84:7413-7417.

11. Figge, J., C. Wright, C. J. Collins, T. M. Roberts, and D. M. Livingston. 1988. Stringent regulation of stably integrated chloramphenicol acetyl transferase genes by $E$. coli lac repressor in monkey cells. Cell 52:713-722.

12. Friedman, R., and G. Stark. 1985. $\alpha$-Interferon-induced transcription of HLA and metallothionein genes containing homologous upstream sequences. Nature (London) 314:637-639.

13. Fuerst, T. R., M. P. Fernandez, and B. Moss. 1989. Transfer of the inducible lac repressor/operator system from Escherichia coli to a vaccinia virus expression vector. Proc. Natl. Acad. Sci. USA 86:2549-2553.

14. Gorman, C. M., L. F. Moffat, and B. H. Howard. 1982. Recombinant genomes which express chloramphenicol acetyltransferase in mammalian cells. Mol. Cell. Biol. 2:1044-1051.

15. Hu, M. C.-T., and N. Davidson. 1987. The inducible lac operator-repressor system is functional in mammalian cells. Cell 48:555-566.

16. Hu, M. C.-T., and N. Davidson. 1988. The inducible lac operator-repressor system is functional for control of expression of injected DNA in Xenopus oocytes. Gene 62:301-313.
17. Hynes, M. E., N. Kennedy, U. Rahmsdorf, and B. Groner. 1981. Hormone-responsive expression of an endogenous proviral gene of mouse mammary tumor virus after molecular cloning and gene transfer into cultured cells. Proc. Natl. Acad. Sci. USA 78:2038-2042.

18. Imbra, R. J., and M. Karin. 1987. Metallothionein gene expression is regulated by serum factors and activators of protein kinase C. Mol. Cell. Biol. 7:1358-1363.

19. Karin, M., A. Haslinger, A. Heguy, T. Dietlin, and T. Cooke. 1987. Metal-responsive elements act as positive modulators of human metallothionein- $\mathrm{II}_{\mathrm{A}}$ enhancer activity. Mol. Cell. Biol. 7:606-613.

20. Karin, M., A. Haslinger, H. Holtgreve, G. Cathala, E. Slater, and J. D. Baxter. 1984. Activation of a heterologous promoter in response to dexamethasone and cadmium by metallothionein gene 5'-flanking DNA. Cell 36:371-379.

21. Karin, M., A. Haslinger, H. Holtgreve, R. I. Richards, P. Krauter, H. M. Westphal, and M. Beato. 1984. Characterization of DNA sequences through which cadmium and glucocorticoid hormones induce human metallothionein- $\mathrm{II}_{\mathrm{A}}$ gene. Nature (London) 308:513-519.

22. Labow, M. A., S. B. Baim, T. Shenk, and A. J. Levine. 1990. Conversion of the lac repressor into an allosterically regulated transcriptional activator for mammalian cells. Mol. Cell. Biol. 10:3343-3356.

23. Lee, W., A. Haslinger, M. Karin, and R. Tjian. 1987. Activation of transcription by two factors that bind promoter and enhancer sequences of the human metallothionein gene and SV40. Nature (London) 325:368-372.

24. Lee, W., P. Mitchell, and R. Tjian. 1987. Purified transcription factor AP-1 interacts with TPA-inducible enhancer elements. Cell 49:741-752.

25. Liu, H.-S., E. S. Feliciano, and P. J. Stambrook. 1989. Сytochemical observation of regulated bacterial $\beta$-galactosidase gene expression in mammalian cells. Proc. Natl. Acad. Sci. USA 86:9951-9955.

26. Lopata, M. A., D. W. Cleveland, and B. Sollner-Webb. 1984. High level transient expression of a chloramphenicol acetyl transferase gene by DEAE-dextran mediated DNA transfection coupled with a dimethyl sulfoxide or glycerol shock treatment. Nucleic Acids Res. 12:5707-5717.

27. Mitchell, P. J., and R. Tjian. 1989. Transcriptional regulation in mammalian cells by sequence-specific DNA binding proteins. Science 45:371-245.

28. Moreau, P., R. Hen, B. Wasylyk, R. Everett, M. P. Baub, and P. Chambon. 1981. The SV40 72 base repair has a striking effect on gene expression both in SV40 and other chimeric recombinants. Nucleic Acids Res. 9:6047-6068.

29. Muller, H.-P., J. M. Sogo, and W. Schaffiner. 1989. An enhancer stimulates transcription in trans when attached to the promoter via a protein bridge. Cell 58:767-777.

30. Muller, M. M., T. Gester, and W. Schafiner. 1988. Enhancer sequences and the regulation of gene transcription. Eur. J. Biochem. 176:485-495.

31. Pace, H. C., P. Lu, and M. Lewis. 1990. lac repressor: crystallization of intact tetramer and its complexes with inducer and operator DNA. Proc. Natl. Acad. Sci. USA 87:1870-1873.

32. Ptashne, M. 1986. Gene regulation by proteins acting nearby and at a distance. Nature (London) 322:697-701.

33. Ptashne, M. 1988. How eukaryotic transcriptional activators work. Nature (London) 335:683-689.

34. Sadler, J. R., H. Sasmor, and J. L. Betz. 1983. A perfectly symmetric lac operator binds the lac repressor very tightly. Proc. Natl. Acad. Sci. USA 80:6785-6789.

35. Schule, R., M. Muller, C. Kaltschmidt, and R. Renkawitz. 1988. Many transcription factors interact synergistically with glucocorticoid receptor. Science 242:1418-1420.

36. Serfling, E., M. Jasin, and W. Schaffner. 1985. Enhancers and eukaryotic gene transcription. Trends Genet. 1:224-230.

37. Strahle, U., W. Schmid, and B. Schutz. 1988. Synergistic interaction of the glucocorticoid receptor with transcription factors. EMBO J. 7:3389-3395.

38. Sussman, D. J., and G. Milman. 1984. Short-term, high-effi- 
ciency expression of transfected DNA. Mol. Cell. Biol. 4:16411643.

39. Takahashi, K., M. Vigneron, H. Matthes, A. Wildeman, M. Zenke, and P. Chambon. 1986. Requirement of stereospecific alignments for initiation from the simian virus 40 early promoter. Nature (London) 319:121-126.
40. Yanisch-Perron, C., J. Vieira, and J. Messing. 1985. Improved M13 phage cloning, vectors and host strains: nucleotide sequences of the M13mp18 and pUC19 vectors. Gene 33:103-119.

41. Zoller, M., and M. Smith. 1984. Oligonucleotide-directed mutagenesis: a simple method using two oligonucleotide primers and a single-stranded DNA template. DNA 3:479-488. 